University of New Haven

University of

New Haven

Digital Commons@ New Haven

$5-2017$

\title{
Vulnerability of Coastal Connecticut to Sea Level rise: Land Inundation and Impacts to Residential Property
}

Rebecca Andreucci

University of New Haven

Can B. Aktas

University of New Haven, caktas@newhaven.edu

Follow this and additional works at: https://digitalcommons.newhaven.edu/civilengineeringfacpubs

Part of the Civil Engineering Commons

\section{Publisher Citation}

Andreucci, R., \& Aktas, C. B. (2017). Vulnerability of coastal Connecticut to sea level rise: land inundation and impacts to residential property. Civil Engineering and Environmental Systems, 34(2), 89-103.

\section{Comments}

This is the authors' accepted version of the article published in Civil Engineering and Environmental Systems. The version of record can be found at http://dx.doi.org/10.1080/10286608.2017.1325878. 


\section{Assessing the Vulnerability and Resilience of Coastal \\ 2 Connecticut to Sea Level Rise}

3 Rebecca Andreucci a, Can B. Aktas a,

4

$5{ }^{a}$ University of New Haven, Department of Civil and Environmental Engineering, 300 Boston

6 Post Rd, West Haven, CT 06516

7 * Corresponding author - Tel: +1-203-479-4131 Email: caktas@newhaven.edu

9 Abstract

11 vulnerability assessments to prepare for future natural disasters and to provide a step towards the

12 eventual development of resilience management plans. The goal of this study was to assess the

13 vulnerability of coastal communities in the state of Connecticut to the impacts of sea level rise

14 together with an analysis of the extent of inundated land and the economic impacts of such

15 environmental phenomenon. Societal impacts as well as impacts on critical infrastructure were

16 also investigated. The scope of the study focused on precision at the local level rather than

17 regional generalizations. Impacts have been assessed at the municipality level, parcel by parcel.

18 The shoreline of New Haven County, which was analyzed in this study, consists of seven

19 municipalities located in the south central region of the state of Connecticut, in the U.S. The

20 study analyzed impacts for $1 \mathrm{~m}$ and $2 \mathrm{~m}$ sea level rise scenarios. Land inundation was calculated

21 as $15 \mathrm{~km}^{2}$ and $25 \mathrm{~km}^{2}$ for the two scenarios. The direct economic cost through residential

22 property losses in the seven municipalities analyzed was estimated to be $\$ 1.3$ billion and $\$ 2.2$

23 billion due to land inundation and flooding, for $1 \mathrm{~m}$ and $2 \mathrm{~m}$ sea level rise scenarios,

24 respectively. The estimated economic impacts to residential property is significant when 
25 considering that only seven municipalities stretching $94 \mathrm{~km}$ of coastline were analyzed in the

26 study. The overall weighted average was $\$ 15$ million $/ \mathrm{km}$ coastline and $\$ 24$ million $/ \mathrm{km}$ coastline

27 for $1 \mathrm{~m}$ and $2 \mathrm{~m}$ sea level rise, respectively. These values do not take into account increased

28 flood risk during storm events, which are expected to increase in frequency and severity, and

29 therefore may be considered to be conservative.

30 Effects of sea level rise would be felt at the local level, which is unique for every

31 location, and so should be the potential solutions. A variety of strategies have been identified that

32 could be applied to the municipalities analyzed, including implementing green infrastructure in

33 the form of restoring wetlands and creating living shorelines, adjusting building codes and

34 zoning ordinances, and reinforcing existing infrastructure.

36 Keywords: Resilience; Sea level rise; GIS; Coastal flood vulnerability assessment; Adaptation 37 planning

39 Highlights:

40 - Estimated residential property losses of $\$ 1.3$ billion for a $1 \mathrm{~m}$ sea level rise

41 - Average economic cost at $\$ 15$ million $/ \mathrm{km}$ coastline for a $1 \mathrm{~m}$ sea level rise

42 - $15 \mathrm{~km}^{2}$ land inundated with a $1 \mathrm{~m}$ sea level rise over a $94 \mathrm{~km}$ coastline

43 - Properties that lie adjacent to inland waters or rivers are equally vulnerable

44 - Wetlands and open spaces expected to undergo drastic changes moving forward 


\section{$46 \quad 1$ Introduction}

47 Following the increase in large storm events and the resulting period of intense flooding,

48 coastal communities have begun developing vulnerability assessments to prepare for future

49 disasters of similar magnitude and intensity (Seenath et al., 2016). Such assessments provide a

50 fundamental first step in the eventual development of robust resilience management plans.

51 Therefore, such assessments play a key role in helping communities look towards the future and

52 plan for potential changes. However, spatial information at a detailed scale useful to those

53 responsible for mitigating the local effects of natural hazards are typically not available (Lichter

54 and Felsenstein, 2012).

55 Despite the state of Connecticut's shoreline being severely impacted by Hurricane Sandy

56 in 2012, resiliency planning has not been as proactive as that in neighboring states. After the

57 devastation of flooding events, state and local officials were most concerned with rebuilding

58 homes and infrastructure where they stood prior to destruction, perhaps with the addition of

59 minor features such as storm shutters and disaster-proof windows (CT DOH, 2013). However,

60 these measures will only be good until an even larger storm or flood event devastates the coastal

61 region, which are expected to occur more frequently than past trends for the region. Rather than

62 solely diverting resources to rebuild damaged property, communities in Connecticut should focus

63 on long term climatic trends that affect the region and various strategies to minimize future

64 impacts. The first step in this process would be to precisely identify regions at high-risk, quantify

65 the magnitude of the risk, and evaluate the potential future consequences.

66 The goal of this study was to assess the vulnerability of coastal communities in the state

67 of Connecticut to the impacts of sea level rise together with an analysis of the extent of 
68 inundated land and the economic impacts of such environmental phenomenon. Societal impacts

69 as well as impacts on critical infrastructure were also investigated.

While there are studies with comparable goals conducted at the national or regional level,

71 effects of sea level rise would be felt at the local level, which would be unique for every location,

72 and so should the potential solutions (Department of Climate Change, 2009; Kuhn et al., 2014).

73 The scope of the study focused on precision at the local level rather than regional or national

74 generalizations. Impacts have been assessed at the municipality level, parcel by parcel.

75

76

77

78

79

80

\subsection{Climate change and sea level rise}

In the past century, the New England region has experienced 12 inches $(0.3 \mathrm{~m})$ of sea level rise (Horton et al., 2014). Sea level is predicted to rise between $0.5 \mathrm{~m}$ and $2 \mathrm{~m}$ by the end of the century if current climate trends continue to yield a $4^{\circ} \mathrm{C}$ increase in average temperature (Nicholls et al., 2011). While the maximum sea level rise expected by 2100 is near 2 meters, sea levels are expected to continue to rise at an accelerated speed for the next several centuries due to the momentum in climate patterns (Parris et al., 2012).

It is estimated that 8 million people live in vulnerable coastal areas in the United States alone, with the majority of these areas within 1-m elevation of sea level (Williams, 2013).

4 Coastal megacities are growing in frequency, with most new development focused in these areas (Nicholls et al., 1995). At the global level, Hinkel et al. (2014) estimate that $0.2-4.6 \%$ of human populations would experience annual flooding by the year 2100, with an expected drop in global gross domestic product of $0.3-9.3 \%$. Adaptation measures to reduce the occurrence and impacts of flooding were reported to require annual investments in the order of $\$ 12-71$ billion. However, it is worth noting that the study by Hinkel et al. (2014) was based on a sea level rise of 0.25-1.2 $\mathrm{m}$, and hence may be a low-end estimate for potential impacts. 
Furthermore, erosion becomes an increasingly large issue as sea level rises (Smith, 2006;

92 Gedan et al., 2011). Erosion taking place in areas with developed shorelines threatens the

93 destruction of coastal property (Kettle, 2012), increasing the risk of insured damages, and the

94 loss of human life (Gedan et al., 2011).

95 Changing climate patterns have important implications for coastal communities. Sea level

96 rise, while being of utmost importance, is not the only phenomenon coastal communities need to

97 plan for. The Intergovernmental Panel on Climate Change (IPCC) has predicted increased

98 precipitation across the Northeast region of the U.S., alongside greater frequency of hurricanes

99 and extreme flood events impacting the region (Christensen et al., 2013; Parr et al., 2015; Sweet

100 et al., 2014). Sea level rise also has the ability to magnify the damage potential of smaller storms

101 that would not have caused a great impact on their own. Inland areas that rarely experience

102 flooding now could, with a higher mean sea level. Gornitz et al. (2002) report that metropolitan

103 areas in the U.S. Northeast could experience a 100-year storm flood event once in 19 years by

1042050 , and once in 4 years by 2080 in the most extreme scenario. The effects of these storms

105 could potentially be catastrophic for the society and economy.

106 The state of Connecticut has already been impacted by the severe impacts of climate

107 change; Hurricane Sandy devastated the coastal communities throughout New England in 2012.

108 The Federal Emergency Management Agency (FEMA) has allocated \$125.9 million towards

109 recovery efforts in New England following the natural disaster (FEMA, 2013). Additionally, the

110 Department of Housing and Urban Development (HUD) has provided Connecticut with \$71.8

111 million to assist in the recovery process (HUD, 2013). However, these numbers are dwarfed by

112 the estimated cost of $\$ 71$ billion for the U.S. 
114 homeowners were still allowed to rebuild in the same high-risk areas. They would only be 115 required to partake in Flood Resistant Construction, using stronger materials that would lessen 116 damage from future storms and the addition of protective building measures (CTDOH, 2013).

117 However, these limited measures are at the individual building level and do not translate into 118 local or regional plans or changes that would be necessary to change the outcome of another 119 storm of equal or higher intensity that would strike in the future. To that end, the desired 120 improvements in regional resilience are not realizable through these efforts alone. The potential 121 impacts of a future storm of similar or stronger magnitude, occurring more frequently, could be 122 catastrophic (NOAA, 2016).

Broadly stated, vulnerability is defined as the potential for loss. More specifically, the

125 United Nations Disaster Relief Organization defines it as the measure of the hazard risk

126 multiplied by damage potential (Wu et al., 2002). Vulnerability assessments are not one-size-fits-

127 all but must be analyzed at the local or regional level. The concept of vulnerability is used to

128 describe the characteristics of a geography related to their ability to anticipate, cope with, resist, 129 and recover from the impact of a natural hazard (Maantay and Maroko, 2009; Taramelli et al., 130 2015). These characteristics rely not only on the geology of the area, but also on the types of 131 infrastructure impacted, social groups existing there, and economic characteristics (Boruff et al., 132 2005; Kunte et al., 2014). Generally, areas with aging infrastructure or those containing large 133 minority or low-income populations are more vulnerable to disaster than wealthy communities 134 with new infrastructure (Maantay and Maroko, 2009). 
Resilience, on the other hand, measures a geography's mechanisms in place to reduce the

136 impact of natural hazards. These could include solid structures and natural infrastructure along

137 the coast to reduce flooding potential, land use and zoning regulations that limit development

138 along the coast and in other flood-prone areas, and up-to-date disaster preparedness plans that

139 allow communities to respond to disaster in a timely manner (Goklany, 2007; Hamin and Gurran, 140 2009).

141 The local geography is not the only factor used in evaluating vulnerability and resiliency;

142 breaking down the population into segments is important in measuring social vulnerability

143 (Nicholls and Vega-Leinert, 2008; Özyurt and Ergin, 2010). A study by Arkema et al. (2013)

144 found that the poor and the elderly are more vulnerable than other segments of a community.

145 When doing analysis of vulnerability and resiliency, it is just as important to include social

146 factors as it is geographical information (Cutter, 2005).

147 The use of Geographic Information Systems (GIS) has been a key component of many

148 vulnerability assessments, allowing communities to locate their most critical areas and plan

149 accordingly (Wu et al., 2002; Schleupner, 2007; Taramelli et al., 2015; Seenath et al., 2016).

150 These assessments allow local and regional governments to plan for a future of uncertainty, 151 using readily available data.

1522 Methods

153 Identification of high-risk zones and communities together with economic and social data

154 through the integration of multiple spatial layers was conducted using ArcGIS version 10.3. Data

155 collected for this analysis included:

156 - Connecticut Town polygon shapefile (CT DEEP, 2005a)

157 - Connecticut Waterbody polygon shapefile (CT DEEP, 2005b) 
- Elevation raster for New Haven County (USDA, 2000)

- Sea level rise estimates (NOAA, 2016)

- Census Block polygon shapefile (UCONN MAGIC, 2010)

- 2014 Median House Values per Census Block (ACS, 2014a)

- 2014 Median Household Income per Census Block (ACS, 2014b)

- Parcel Land Use polygon shapefile (SCRCOG, 2008)

- Critical Infrastructure points shapefile (SCRCOG, 2016)

167 IPCC and NOAA, this analysis used values of 1 and 2 meter sea level rise scenarios. Land that would be inundated by a rise was highlighted in the analysis, and developed land and parcels that 169 would be affected were identified.

Data from the 2015 American Community Survey (ACS) was obtained through the

171 Census database, containing information on median household values based on census block.

172 The data was joined with the Census Block polygons, and was used in conjunction with parcel 173 land use data. By intersecting these layers together, a new shapefile was created that listed the 174 median home value for every parcel in each municipality analyzed. This new shapefile was the 175 basis for the economic impact section of this study. The median household values of residential 176 parcels that intersected the $1 \mathrm{~m}$ and $2 \mathrm{~m}$ sea level rise polygons were summed for each town, and 177 for each scenario of sea level rise.

The economic analysis was carried out using parcel data that shows the location of the 179 parcel but not the location of the building within the parcel. Therefore, it was assumed that any 180 presence of flooding within the parcel would result in an economic loss equal to the worth of the 181 parcel and hence the value of the property. The assumption is not unrealistic when the effects of 182 tides, heavy precipitation events that might lead to local flooding, or the effects of coastal 183 erosion associated with rising sea levels are considered. 
A separate analysis was done to understand the impact of sea level rise on critical

185 infrastructure, such as hospitals, schools, and public transit centers. The critical infrastructure

186 dataset was overlaid onto the map of the seven towns and intersected with the $1 \mathrm{~m}$ and $2 \mathrm{~m}$ sea

187 level rise scenarios. The result is a list of each town's critical infrastructure that would be

188 impacted by sea level rise.

189 Social vulnerability was assessed through the integration of income data at the census

190 block scale with the sea level rise maps gathered from the previous steps. Income ranges

191 provided by the Current Population Survey conducted by the U.S. Census Bureau were used in

192 the study, and the residents were effectively grouped into five categories: low income $(\leq \$ 21430)$;

193 lower-middle income (\$21431 - \$41166); middle income (\$41167 - \$68199); upper-middle

194 income (\$68200 - \$112253); and high income ( $\geq \$ 112254)$ (Census, 2015). Furthermore, the

195 percentage of inundated land used by each income group was calculated in conjunction with the

196 total land area inundated for each group.

197 In line with the goal of the study, the scope was limited to the above mentioned factors.

198 Impacts that may arise from extreme weather events such as potential storm surge flooding were

199 not assessed in the study. While climate models predict more frequent and severe precipitation

200 events for the region as a whole, which can be expected to result in more frequent localized

201 flooding, the impacts of changing precipitation patterns were not included in the study.

\subsection{Study Area}

New Haven County is located in the south central region of the state of Connecticut, in

204 the U.S. It contains a total of 27 municipalities, with seven of them falling along the coast of

205 Long Island Sound. From west to east, these seven municipalities are: Milford; West Haven; 
New Haven; East Haven; Branford; Guilford; and Madison. These seven municipalities have

207 been studied for their vulnerability to the effects of sea level rise and their resilience.

209 the Long Island Sound coast are presented in Figure 1. These coastal towns have a combined

210 population of 336,029 residents, that make up more than a third of the county's, and nearly one-

211 tenth of the state's total population (Census, 2010). The region is predominately flat, gradually

212 changing to rolling hills further inland. The towns along the coast are varied in composition,

213 ranging from highly industrialized to primarily residential with large areas of open space. Table

2141 breaks down the land use type in each of the seven coastal towns analyzed in this study.

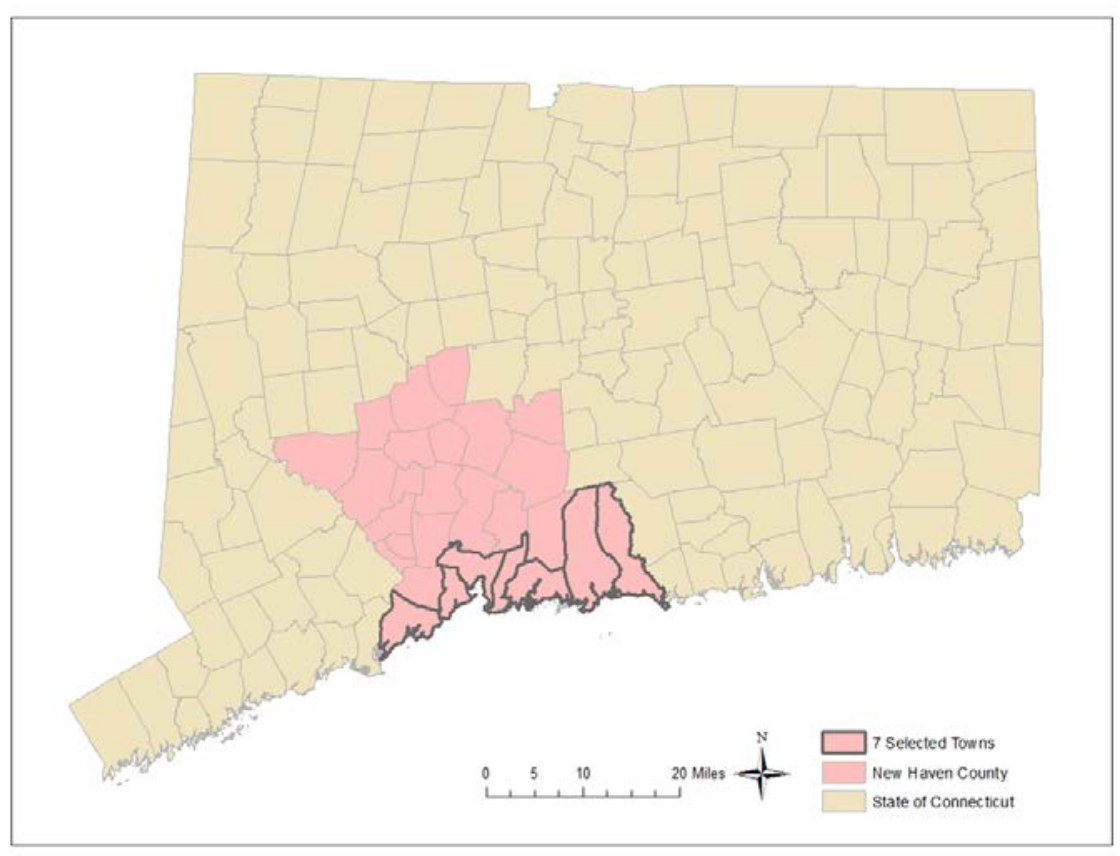

217 Figure 1: Map of Connecticut highlighting New Haven County and the seven coastal 218 municipalities of the region analyzed in the study. 
221 Table 1: Land use type and percentage in each of the seven selected municipalities

\begin{tabular}{|c|c|c|c|c|}
\hline \multirow[t]{2}{*}{ Municipality } & \multicolumn{4}{|l|}{ Land Use Type } \\
\hline & Residential, \% & Commercial, \% & Industrial, \% & Open Space, \% \\
\hline Branford & 45 & 5 & 6 & 29 \\
\hline East Haven & 47 & 7 & 7 & 10 \\
\hline Guilford & 48 & 2 & 1 & 40 \\
\hline Madison & 45 & 1 & 0 & 42 \\
\hline Milford & 51 & 8 & 8 & 9 \\
\hline New Haven & 35 & 7 & 8 & 21 \\
\hline West Haven & 43 & 6 & 9 & 15 \\
\hline
\end{tabular}

222

\section{$223 \quad 3$ Results and Discussion}

224 Results of the analysis indicate that the seven coastal towns analyzed have varying levels

225 of vulnerability to sea level rise. Figure 2 depicts the estimated sea level rise land cover at 1 and

2262 meters. It highlights that the impacts will be felt primarily along the shoreline, while inland

227 communities situated along rivers that drain into Long Island Sound are equally at risk of

228 flooding at least as much as those along the shoreline. 


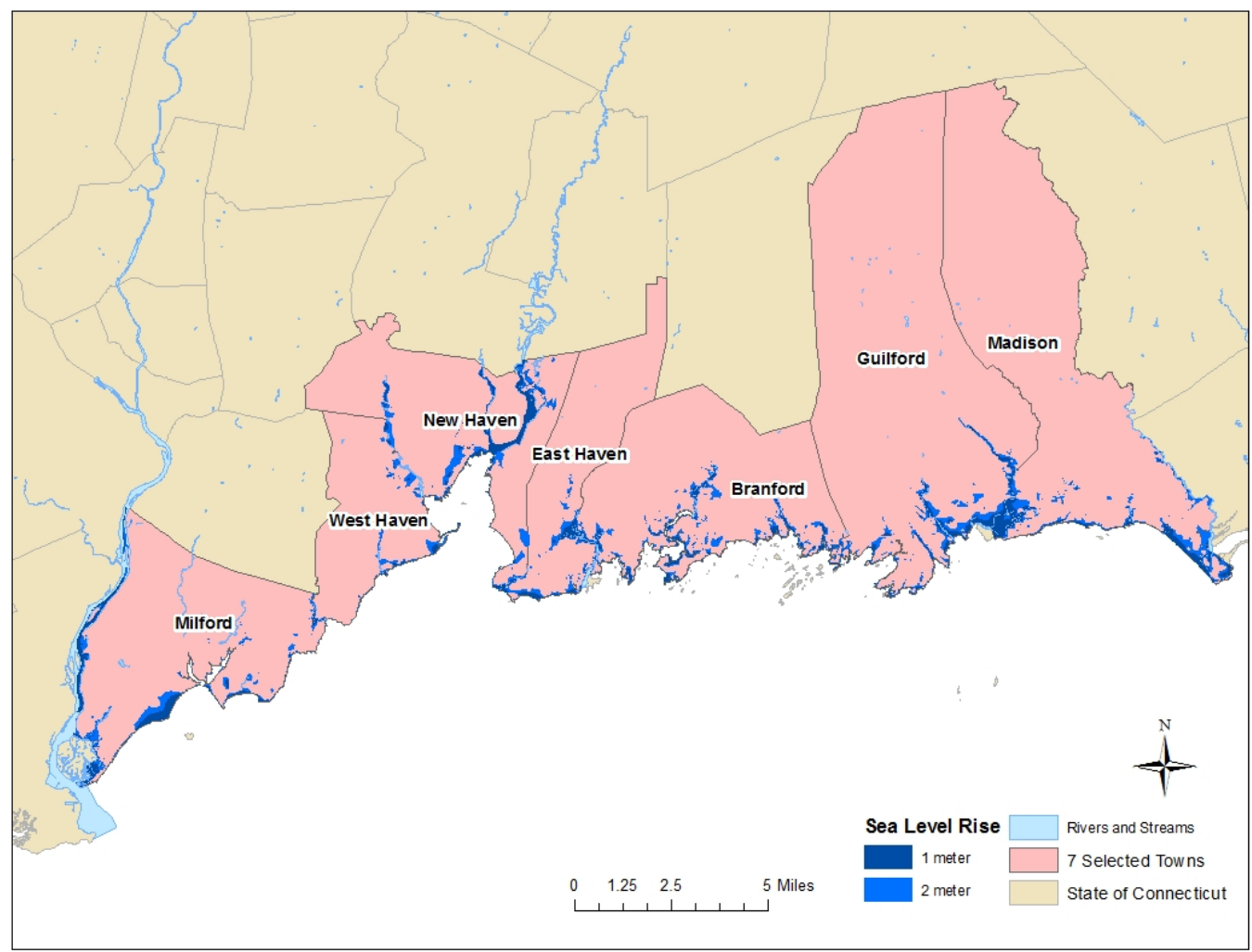

230 Figure 2: Map depicting the area affected by 1 meter and 2 meter sea level rise scenarios for the seven municipalities analyzed in New Haven County, Connecticut

234 development pattern along the shoreline due to economic, social, or historical differences. While 235 East Haven and Milford have predominantly residential coastlines, New Haven and West Haven 236 are industrial in the way they were planned and developed. Therefore, the social and economic 237 impacts of sea level rise were found to be different among the seven adjacent towns analyzed. 238 Figure 3 shows the areas of the region that have the highest social vulnerability based on income 239 ranges used in the study. Census blocks shaded in red report income below $\$ 21400$ designated as 240 the lowest quintile by the U.S. Census Bureau, whereas the light green and dark green areas are 241 upper-middle and high income areas, respectively. Figure 3 indicates that the income level of 
242 shoreline residents is not uniform across the seven municipalities. While the majority of Guilford

243 and Madison residents fall into upper-middle to high income quantiles, West Haven and New

244 Haven residents fall into lower-middle to middle income quantiles, with sporadic low income

245 communities. While those extremely vulnerable regions were not directly along the coastline but

246 rather concentrated inland, still, the proximity of rivers and inland waters puts these communities

247 at an increased level of vulnerability. Table 2 presents the area of land estimated to be inundated

248 under both a $1 \mathrm{~m}$ and a $2 \mathrm{~m}$ sea level rise and the breakdown of total inundation based on income

249 quintiles.

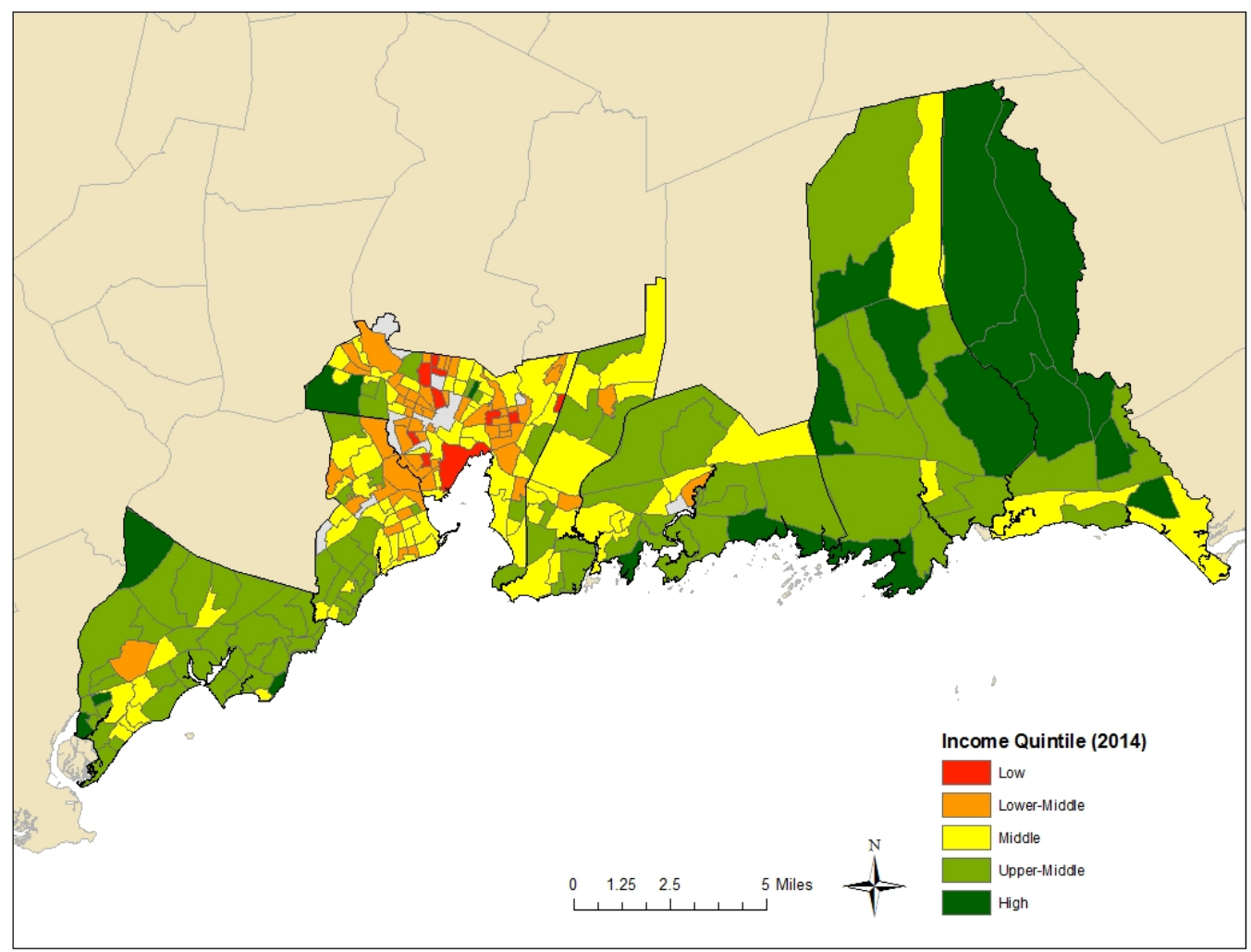

250

251 Figure 3: Social vulnerability of each census block based on income. 
252 Table 2: Inundated land area and percentage of total inundation for each income quantile 253 according to average household income for census blocks for both $1 \mathrm{~m}$ and $2 \mathrm{~m}$ sea level rise

\begin{tabular}{llllll}
\hline Income Quintile & $\begin{array}{l}\text { Household } \\
\text { Income (\$) }\end{array}$ & \multicolumn{2}{l}{$\mathbf{1}$ m Sea Level Rise } & \multicolumn{2}{c}{$\mathbf{2 ~ m ~ S e a ~ L e v e l ~ R i s e ~}$} \\
\cline { 3 - 6 } & & $\begin{array}{l}\text { Land } \\
\text { Inundation } \\
\left(\mathrm{km}^{2}\right)\end{array}$ & $\begin{array}{l}\text { Percentage } \\
\text { of Total } \\
\text { Inundation }\end{array}$ & $\begin{array}{l}\text { Land } \\
\text { Inundation } \\
\left(\mathrm{km}^{2}\right)\end{array}$ & $\begin{array}{l}\text { Percentage } \\
\text { of Total } \\
\text { Inundation }\end{array}$ \\
\hline Low & $\leq 21430$ & 0.23 & $2 \%$ & 0.87 & $4 \%$ \\
Lower-Middle & $21431-41166$ & 0.89 & $8 \%$ & 1.75 & $7 \%$ \\
Middle & $41167-68199$ & 4.12 & $37 \%$ & 8.55 & $35 \%$ \\
Upper-Middle & $68200-112253$ & 4.59 & $42 \%$ & 10.41 & $42 \%$ \\
High & $\geq 112254$ & 1.24 & $11 \%$ & 2.85 & $12 \%$ \\
\hline
\end{tabular}

257 of inundation would occur on property owned by middle to upper-middle income populations.

258 However, considering that the parcel sizes were comparatively small in low income properties 259 indicating a larger segment of the population than represented by these numbers alone, together 260 with the fact that these communities would be less likely to be able to afford to move or rebuild 261 as compared to middle and upper-middle income quintile households, such households are at 262 higher vulnerability to the effects of sea level rise or its induced effects.

264 with the estimated economic losses on residential properties. For normalization purposes, the 265 cost of sea level rise per km coastline has also been presented in Table 3. Due to different

266 development patterns and land use, proximity to the shoreline, different topographies, and 267 differing property values, the correlation between land inundation and residential economic 268 impacts was not linear. Neither did the impacts increase linearly from a $1 \mathrm{~m}$ sea level rise to a 2 $269 \mathrm{~m}$ sea level rise due to multiple factors affecting total impacts. 
271 Table 3: Land area that will be inundated under a $1 \mathrm{~m}$ and $2 \mathrm{~m}$ sea level rise and estimated 272 residential property losses. Economic impacts normalized based on length of coastline in each of 273 the seven municipalities were also presented.

\begin{tabular}{|c|c|c|c|c|c|c|c|}
\hline \multirow[t]{2}{*}{ Municipality } & \multirow{2}{*}{$\begin{array}{l}\text { Coastline } \\
(\mathrm{km})\end{array}$} & \multicolumn{3}{|c|}{1 m Sea Level Rise } & \multicolumn{3}{|c|}{2 m Sea Level Rise } \\
\hline & & $\begin{array}{l}\text { Total } \\
\text { inundated } \\
\text { land } \\
\left(\mathrm{km}^{2}\right)\end{array}$ & $\begin{array}{l}\text { Residential } \\
\text { property } \\
\text { loss (\$ } \\
\text { million) }\end{array}$ & $\begin{array}{l}\text { Residential } \\
\text { property loss } \\
\text { per km } \\
\text { coastline (\$ } \\
\text { million / } \\
\mathrm{km})\end{array}$ & $\begin{array}{l}\text { Total } \\
\text { inundated } \\
\text { land } \\
\left(\mathrm{km}^{2}\right)\end{array}$ & $\begin{array}{l}\text { Residential } \\
\text { property } \\
\text { loss (\$ } \\
\text { million) }\end{array}$ & $\begin{array}{l}\text { Residential } \\
\text { property loss } \\
\text { per km } \\
\text { coastline ( } \$ \\
\text { million / } \\
\mathrm{km})\end{array}$ \\
\hline Milford & 20.4 & 2.8 & 320 & 15.7 & 4.5 & 560 & 27.5 \\
\hline Branford & 19.5 & 2.6 & 320 & 16.4 & 3.9 & 540 & 27.7 \\
\hline Guilford & 15.5 & 3.5 & 270 & 17.4 & 4.0 & 390 & 25.2 \\
\hline Madison & 12.8 & 1.4 & 250 & 19.5 & 4.9 & 380 & 29.7 \\
\hline East Haven & 4.0 & 1.5 & 130 & 32.5 & 1.8 & 200 & 50.0 \\
\hline New Haven & 11.0 & 2.9 & 19 & 1.7 & 4.5 & 58 & 5.3 \\
\hline West Haven & 11.0 & 0.7 & 14 & 1.3 & 1.4 & 42 & 3.8 \\
\hline Total & 94.2 & 15 & 1300 & & 25 & 2200 & \\
\hline
\end{tabular}

274

275

276

277

278

279

280

281

282

283

284

285

286

287

288

The social and economic impact of inundation is not directly correlated to the amount of

flooded land. The land use characteristics of each town's shoreline plays an important role in the amount of devastation felt by citizens and local governments. Towns with highly developed residential shorelines would feel impacts differently than those with historically industrial shorelines, or those that have been preserved or undeveloped in order to protect marshland and other natural habitat. Wetlands especially play an important role in providing flood control benefits and help dissipate storm surges. As time progresses, these wetlands' ability to handle the influx of sea level rise inundation will gradually decrease, leading to devastation of wetlands as well a decrease in the overall resilience of coastal communities against storm surges or floods. This is important to remember when reviewing the economic analysis of the residential properties impacted by $1 \mathrm{~m}$ and $2 \mathrm{~m}$ sea level rise. The estimated total damage of $\$ 1.3$ and $\$ 2.2$ billion for $1 \mathrm{~m}$ and $2 \mathrm{~m}$ sea level rise scenarios, respectively, is not distributed equally between the towns analyzed. Branford and Milford carry the highest burden of residential damage, with Guilford and Madison following closely behind. The potential residential loss of these four 
towns makes up $86 \%$ of the residential loss of this entire region. While all of the municipalities

290 analyzed had highly developed coastlines, these four towns have developed residential

291 shorelines, with high real estate prices. The remaining three towns of East Haven, West Haven, 292 and New Haven are more unique. East Haven remains relatively unaffected largely due to its 293 comparatively short length of shoreline. West Haven and New Haven on the other hand, still

294 carry the industrial heritage and development patterns that have shaped and defined these cities 295 historically.

As a means to normalize the results and use for further comparison, residential property

297 loss per $\mathrm{km}$ of coastline has also been calculated. Accordingly, average values of $\$ 15$ million $/ \mathrm{km}$ 298 coastline and $\$ 24$ million/ $\mathrm{km}$ coastline has been calculated for a $1 \mathrm{~m}$ sea level rise and $2 \mathrm{~m}$ sea 299 level rise, respectively. The range of results, $\$ 1-33$ million $/ \mathrm{km}$ coastline for the former and $\$ 4-$ 30050 million $/ \mathrm{km}$ coastline for the latter, indicate large variation among the seven neighboring 301 municipalities analyzed. While results of the study can be used to estimate economic impacts for 302 the state of Connecticut that shares similar characteristics and high levels of urbanization, 303 caution is advised before extrapolating results to other regions of the U.S. or other countries.

304 Development patterns and characteristics, and real estate prices are only some of the factors that 305 may lead to differences when these numbers are applied elsewhere.

306 Figures $4-10$ show the residential parcels that are impacted at $2 \mathrm{~m}$ of sea level rise. In 307 addition to the shoreline, properties that lie adjacent to inland waters or rivers were also seen to 308 be susceptible to inundation. Designated wetlands and other open spaces, including a state park, 309 can be expected to undergo drastic changes under a $2 \mathrm{~m}$ sea level rise, as in the case of Guilford 310 and Madison shown in Figures 9 and 10. 


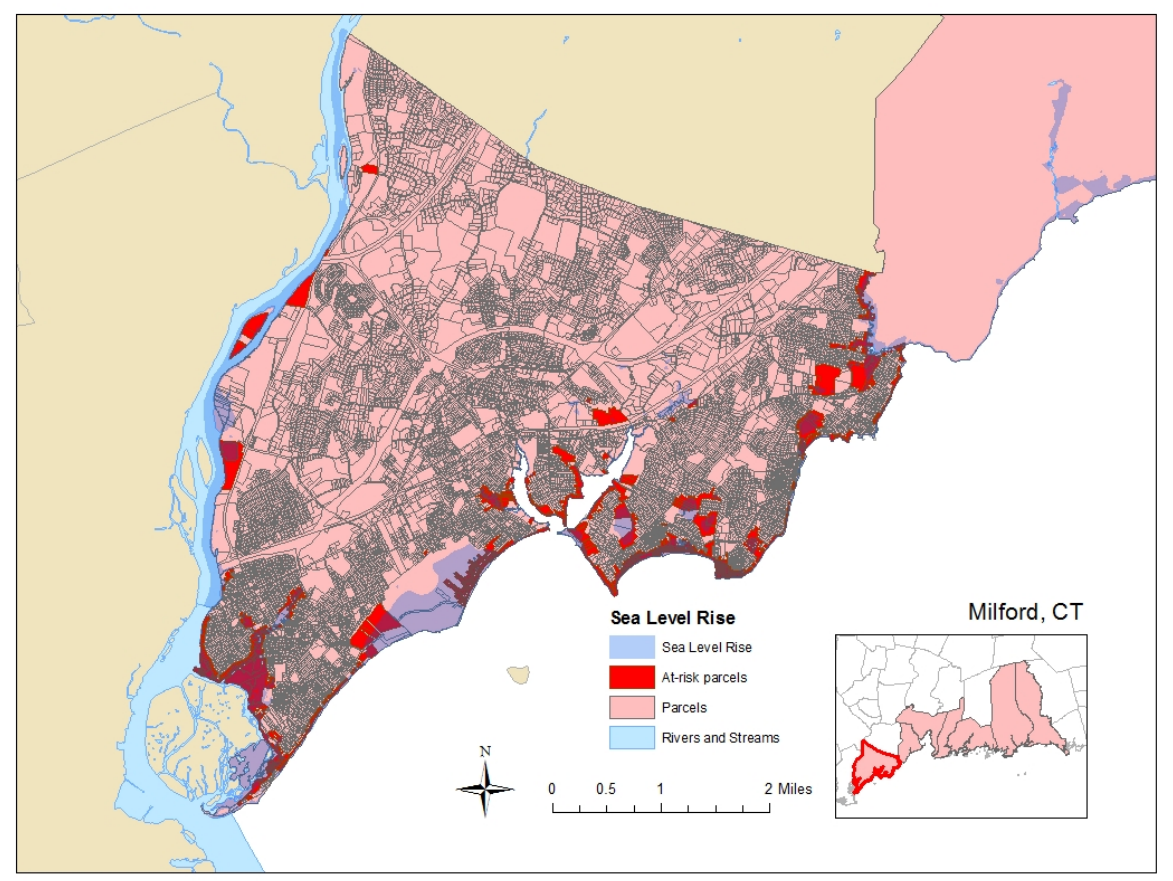

312

313 Figure 4: Impacted residential parcels in Milford, Connecticut at 2 meters of sea level rise

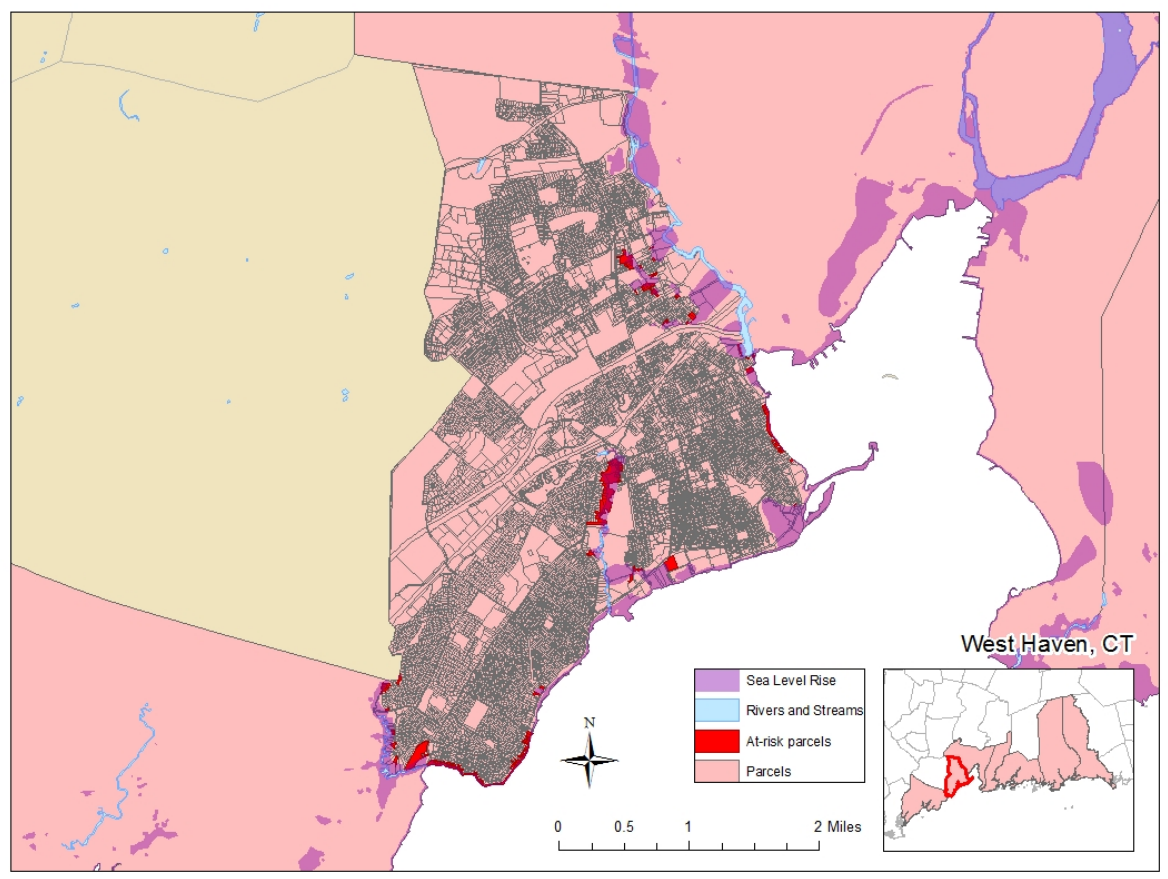

315 Figure 5: Impacted residential parcels in West Haven, Connecticut at 2 meters of sea level rise 


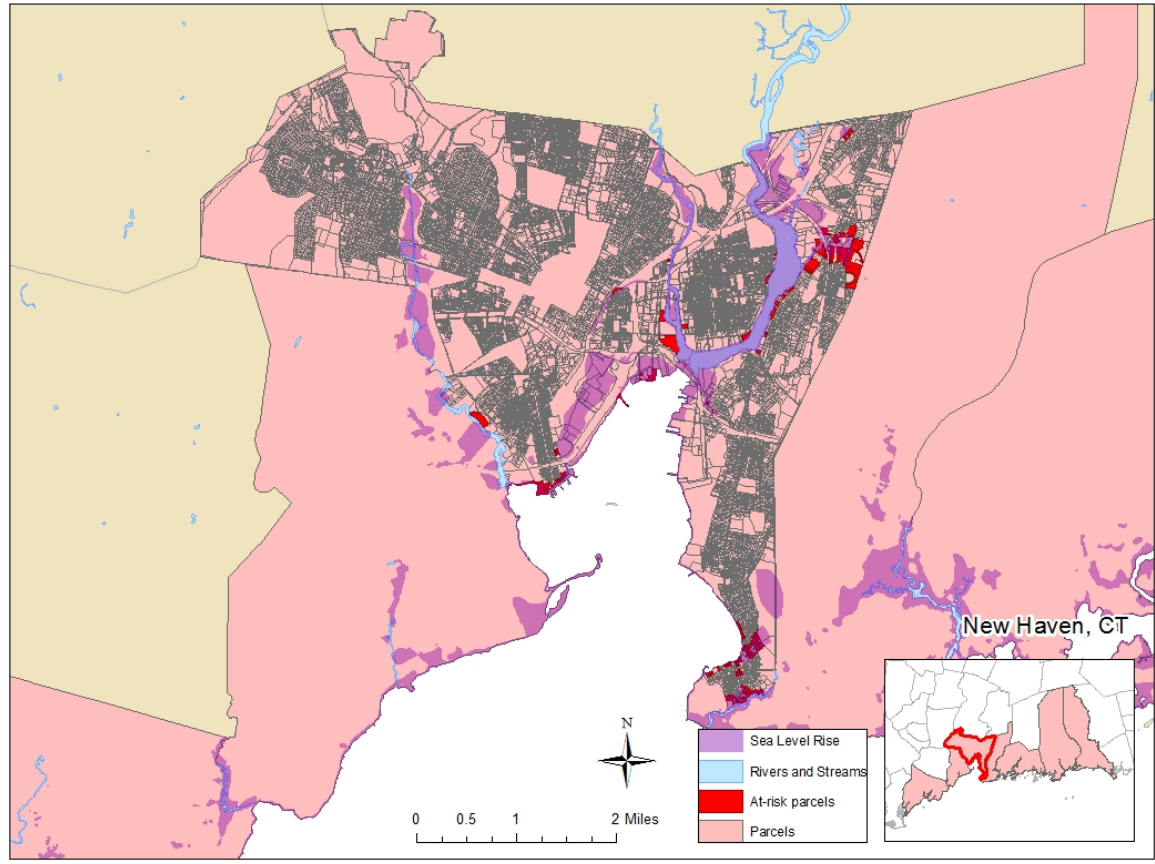

317 Figure 6: Impacted residential parcels in New Haven, Connecticut at 2 meters of sea level rise

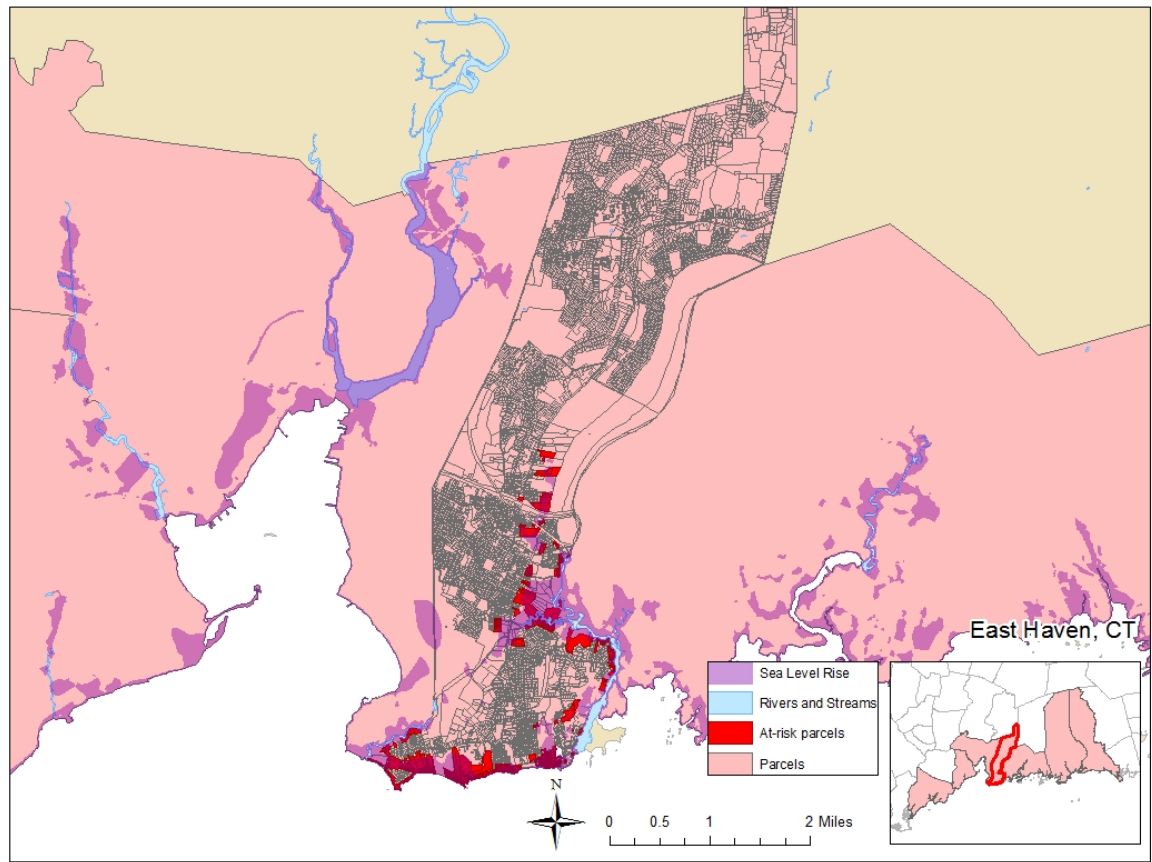

319 Figure 7: Impacted residential parcels in East Haven, Connecticut at 2 meters of sea level rise 


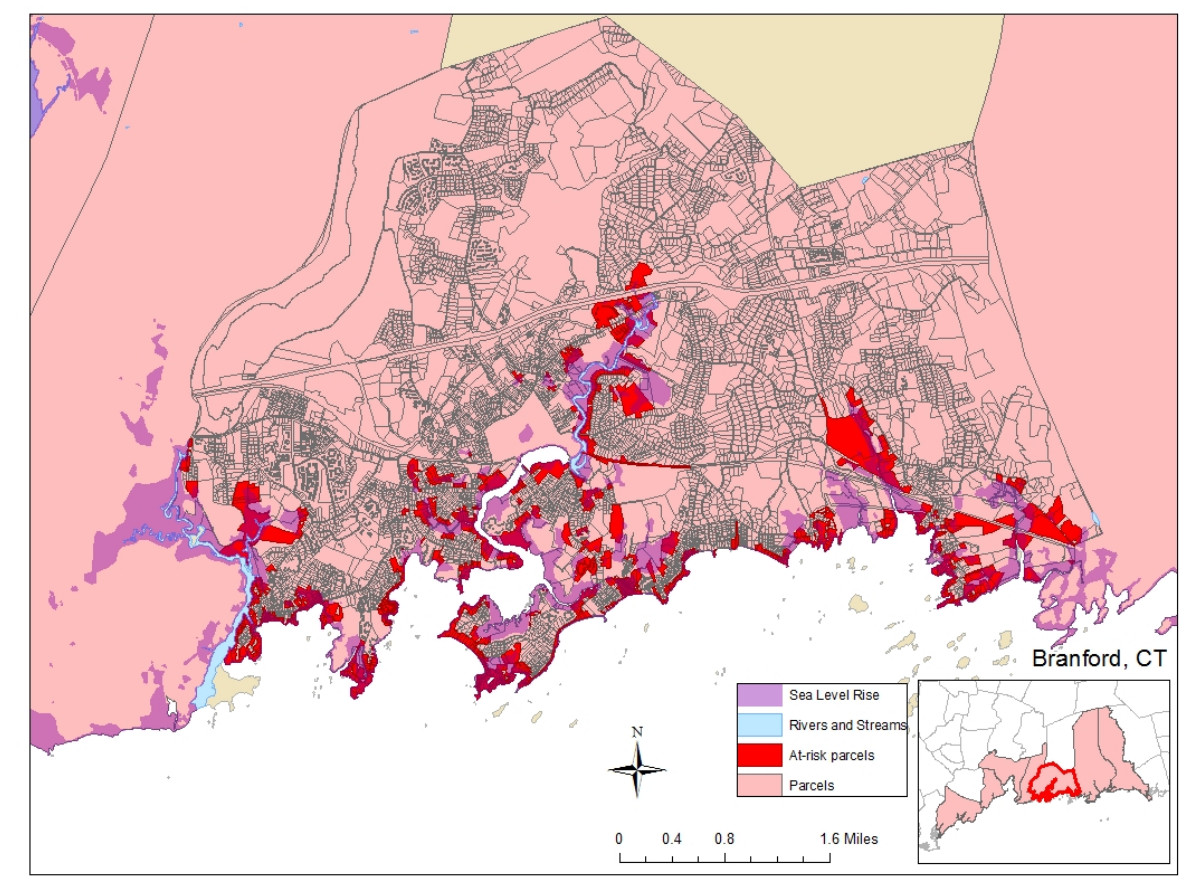

321 Figure 8: Impacted residential parcels in Branford, Connecticut at 2 meters of sea level rise 322

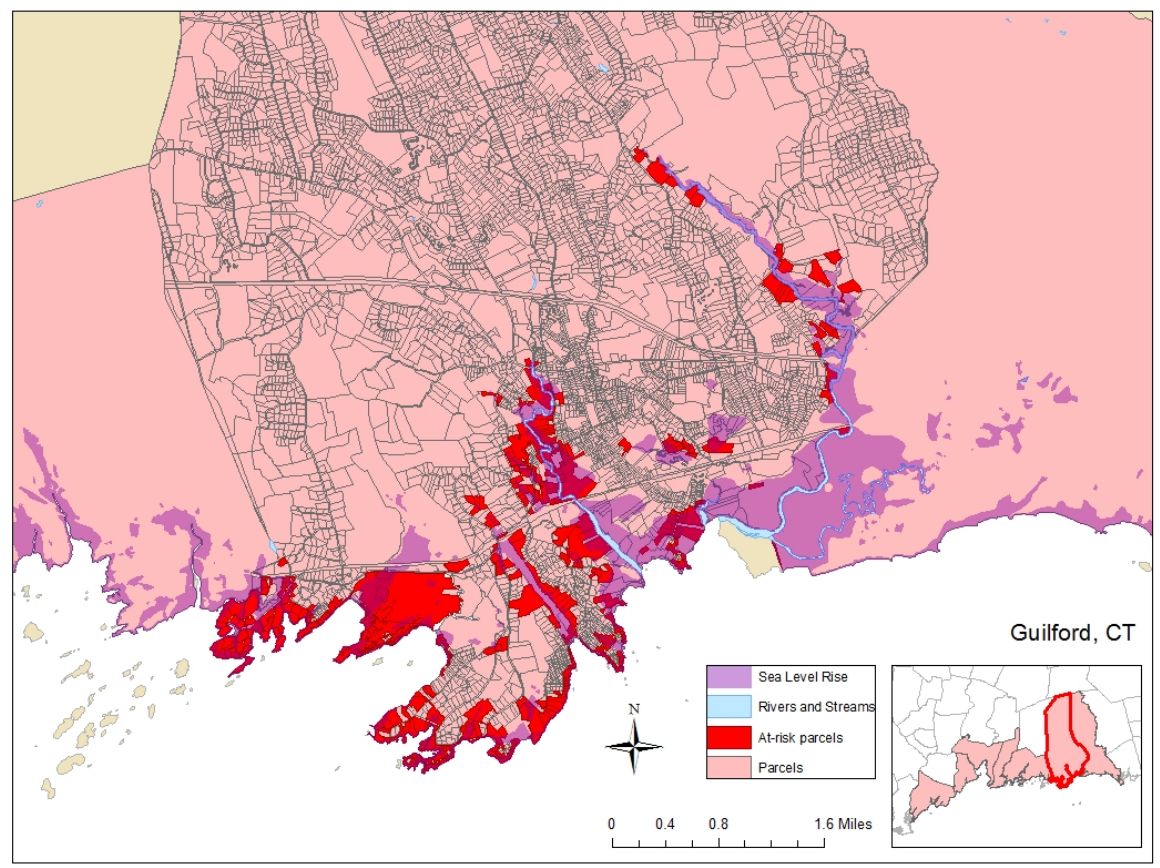

324 Figure 9: Impacted residential parcels in Guilford, Connecticut at 2 meters of sea level rise 


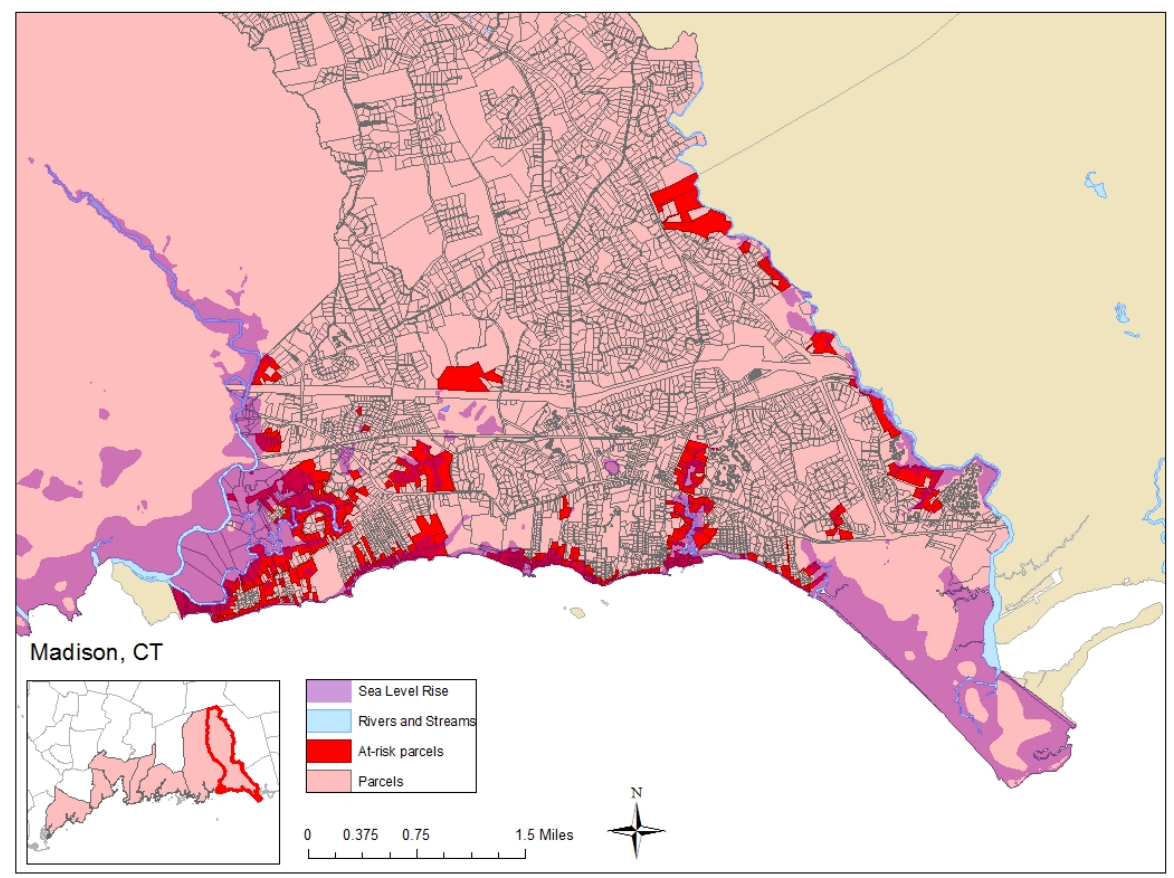

326 Figure 10: Impacted residential parcels in Madison, Connecticut at 2 meters of sea level rise

In order to better assess the impacts of sea level rise on the various land uses of the

329 shoreline, commercial and industrial parcels were included in the analysis. Table 4 compares the

330 inundated land area of municipalities for residential, commercial, and industrial use. Three

331 distinct differences were observed from this analysis. Branford, Guilford, and Madison all share

332 a highly residential shoreline with minimal commercial and industrial property. Milford and East

333 Haven have a unique combination of residential and industrial parcels with very little

334 commercial use on the coast. Lastly, New Haven and West Haven have coastlines with more

335 industrial use than both residential and commercial combined.

These results indicate that commercial and industrial properties would also be impacted

337 by either a $1 \mathrm{~m}$ or a $2 \mathrm{~m}$ sea level rise, in addition to impacts to residential properties. While this

338 has important implications for the local society and economy in the form of amenities, economic 
activity, or number of jobs available, such aspects of impacts to industrial and commercial

340 properties could not be assessed in the study due to a lack of comprehensive data.

342 Table 4: Land area that would be inundated under a 1 meter and 2 meter sea level rise, together 343 with a breakdown of inundation per zoning type

\begin{tabular}{llll}
\hline \multirow{2}{*}{ Municipality } & \multicolumn{3}{l}{ Affected Land $\left(\mathrm{km}^{2}\right)-1 \mathrm{~m} / 2 \mathrm{~m}$ sea level rise } \\
\cline { 2 - 4 } & Residential & Commercial & Industrial \\
\hline Milford & $1.8 / 3.4$ & $0.1 / 0.3$ & $0.9 / 1.2$ \\
Branford & $2.4 / 4.0$ & $0.2 / 0.3$ & $0.0 / 0.0$ \\
Guilford & $3.1 / 4.5$ & $0.3 / 0.4$ & $0.1 / 0.2$ \\
Madison & $1.4 / 2.8$ & $0.0 / 0.2$ & $0.0 / 0.0$ \\
East Haven & $0.8 / 1.3$ & $0.1 / 0.2$ & $0.6 / 0.8$ \\
New Haven & $0.4 / 0.7$ & $0.7 / 1.2$ & $1.8 / 2.3$ \\
West Haven & $0.2 / 0.4$ & $0.1 / 0.2$ & $0.4 / 0.7$ \\
\hline Total & $10.1 / 17.0$ & $1.5 / 2.8$ & $3.8 / 5.2$ \\
\hline
\end{tabular}

347 within the flood zone for a 2 meters sea level rise. The Sound School in New Haven, CT is

348 located on the shoreline and would be completely inundated in the case of a $2 \mathrm{~m}$ sea level rise.

349 However, the critical infrastructure file lacked important facilities such as wastewater treatment 350 plants and public water supply utilities, and energy and electricity generators. Failure of any one 351 of these infrastructure due to the effects of climate change would jeopardize the wellbeing of

352 local residents and their ability to cope with disaster, together with their economic impacts.

\section{Potential Adaptation Strategies}

Until recently, the focus of governmental attention, both federal and local, has been on

355 mitigation of the effects of climate change rather than adaption (Baker and McGowan, 2013).

356 While mitigation efforts are important in limiting the progression of sea level rise, it is important 
357 to note that impacts will be seen within the current century regardless of the proposed

358 international emissions reduction strategies. Therefore, it is important to analyze potential 359 adaptation strategies as part of a coastal resiliency study.

\subsection{Wetlands, living shorelines, and green infrastructure}

362 reducing storm surge and flooding in coastal communities, and successful case studies indicate a

363 high return on investment (Foster et al., 2011; Arkema et al., 2013; APA 2014). While wetlands

364 are predicted to be a powerful tool in mitigating the effects of sea level rise and erosion, many

365 studies have addressed concern that rising seas will reduce the protective capabilities of these

366 ecosystems (Craft et al., 2009; Geden et al., 2011; Kirwan and Megonigal, 2013; Nelson et al.,

367 2013). Due to sea level rise by the end of the century, it is expected that salt marshes will decline

368 in area by $45 \%$ while tidal freshwater marshes will decline by $39 \%$ (Craft et al., 2009).

369 Living shorelines, as an alternative to sea walls, have the ability to manage coastal

370 erosion (Smith, 2006; Swann, 2008). However, there is no universal approach that can be

371 mimicked everywhere, as each location requires a different combination of flora and fauna

372 species, making it difficult to learn from the successes and failures of existing projects and 373 rapidly implement projects (Smith, 2006).

374 Green infrastructure can also be effective at managing inland flooding, restoring the 375 capacity of the natural environment to handle large amounts of water. While traditionally it is 376 used to manage stormwater runoff to minimize pollution to rivers and streams, when

377 implemented on a watershed scale it can reduce flooding from even a large 100-year storm 378 (Medina et al., 2011). Pilot projects of large-scale green infrastructure, such as the Greenstreets 
379 Program in New York City were deemed successful at managing extreme flooding during

380 Hurricane Sandy (NYC, 2013).

Among the seven municipalities analyzed in this study, Guilford and Madison both

382 contain large areas of wetlands, which help to increase their resilience to flooding. Branford,

383 East Haven, and Milford, on the other hand, contain high development along their coastlines,

384 which gives them a different set of challenges. On the opposite side of the spectrum, New Haven

385 and West Haven have highly industrialized coastlines where residential resilience may not be top

386 priority. The response of these different municipalities should be different. Guilford and

387 Madison, which have large areas of residential development to be inundated and therefore large

388 economic impact, should engage in wetlands restoration projects or invest in living shorelines to

389 protect the ecosystems that already exist. Limiting development within and adjacent to the

390 wetlands will provide space for those ecosystems to retreat inland as sea levels rise. All

391 municipalities along the coast can be said to benefit form green infrastructure to manage heavy

392 precipitation induced local flooding.

\subsection{Retreat}

394 While viewed as the least desirable option, retreat from at-risk areas is an option for the 395 most vulnerable communities where other forms of protection would be ineffective. Often, this 396 includes land acquisition, economic incentives for abandonment, and blockage of redevelopment 397 after a natural disaster. Although economic costs of acquiring existing residential homes, and the 398 political cost of blocking future development may be high, the alternative of continually

399 providing state and federal funds for redevelopment may be significantly higher (Alexander et 400 al., 2012; Bray et al. 1997; Salik et al., 2015). 

recommended to limit future shoreline development, and may be faced with relocating some of

403 their current residents and infrastructure further inland, especially if an intense storm results in 404 significant damages similar to those experienced with Hurricane Sandy in 2012. Rather than 405 rebuilding structures in the same spot with similar faults, a proactive approach led by adaptation 406 planning and policy would be recommended as compared to limited reactive actions.

\subsection{Policy and Planning}

409 implementation (Boateng, 2012). This may be realized at the local level through zoning changes 410 or revising building codes such as mandating raised buildings and bridges above predicted future

411 flood-levels (Foster et al., 2011). It may also be supported at the federal level. Insurance is a

412 powerful tool to incentivize against developing in vulnerable areas. However, there is potential

413 for improvement with the current process of evaluating insurance costs. The National Flood

414 Insurance Program under FEMA considers flood elevations for the 100-year storm; elevations

415 that were set in the past based on different precipitation patterns and climatic conditions.

416 Unfortunately, the program falls short in that it does not consider future changes in flooding with 417 climate change driven precipitation changes and sea level rise.

\section{Conclusions}

419 Seven coastal towns in Connecticut were analyzed in this study in terms of their

420 vulnerability to the effects of sea level rise together with an analysis of the extent of land

421 inundation and its economic and societal impacts. Regarding residential properties, the estimated 422 total cost for the seven municipalities was calculated as $\$ 1.3$ billion and $\$ 2.2$ billion for $1 \mathrm{~m}$ and 
$4232 \mathrm{~m}$ sea level rise, respectively. These values are significant when considering that only seven

424 municipalities stretching $94 \mathrm{~km}$ of coastline were analyzed in the study. Furthermore, these

425 values may be deemed conservative as the economic impacts to the commercial and industrial

426 sectors have not been directly captured, but rather were limited to land inundation impacts.

427 This analysis highlights some of the various challenges facing these seven communities,

428 each with somewhat different characteristics and methods to preserve their coastline. Guilford

429 and Madison both contain large areas of wetlands, which help to increase their resilience to

430 flooding. Branford, East Haven, and Milford, on the other hand, contain high development along

431 their coastlines, which gives them a different set of challenges. On the opposite side of the

432 spectrum, New Haven and West Haven have highly industrialized coastlines where residential

433 resilience may not be top priority. The response of these different municipalities should be

434 different. Guilford and Madison, which have large areas of residential development to be

435 inundated and therefore large economic impact, should engage in wetlands restoration projects to

436 protect the ecosystems that already exist. Limiting development within and adjacent to the

437 wetlands will provide space for those ecosystems to retreat inland as sea levels rise. Branford,

438 East Haven, and Milford are recommended to limit future shoreline development, and may be

439 faced with relocating some of their current residents and infrastructure further inland, especially

440 if an intense storm results in significant damages similar to those experienced with Hurricane

441 Sandy in 2012. Rather than rebuilding the structure in the same spot with similar faults, a

442 proactive approach led by adaptation planning and policy would be recommended as compared

443 to limited reactive actions.

444 


\section{Acknowledgements}

446 This research did not receive any specific grant from funding agencies in the public, commercial,

447 or not-for-profit sectors.

448 References

449 Alexander, K. S., Ryan, A., \& Measham, T. G. (2012). Managed retreat of coastal communities: understanding 450 responses to projected sea level rise. Journal of Environmental Planning and Management, 55(4), 409-433.

451 http://doi.org/10.1080/09640568.2011.604193

452 ACS (2014a). Median House Value (Dollars). (Data file). American Community Survey, Washington, D.C.: U.S.

453 Census Bureau.

454 http://factfinder.census.gov/faces/tableservices/jsf/pages/productview.xhtml?pid=ACS_14_5YR_B25077\&prodTyp

$455 \mathrm{e}=$ table

ACS (2014b). Median Household Income in the Past 12 Months (Dollars). (Data file). American Community Survey, Washington, D.C.: U.S. Census Bureau.

http://factfinder.census.gov/faces/tableservices/jsf/pages/productview.xhtml?pid=ACS_14_5YR_B19013\&prodTyp $\mathrm{e}=$ table

APA (2014). Planning for post-disaster recovery briefing papers green infrastructure and post-disaster recovery,

461 American Planning Association.

Arkema, K. K., Guannel, G., Verutes, G., Wood, S. a., Guerry, A., Ruckelshaus, M., ... Silver, J. M. (2013). Coastal http://doi.org/10.1038/nclimate1944

Baker, R. G. V, \& Mcgowan, S. A. (2013). Geographic information system planning for future sea-level rise using

Boateng, I. (2012). GIS assessment of coastal vulnerability to climate change and coastal adaption planning in

472 Bray, M., Hooke, J., \& Carter, D. (1997). Planning for sea-level rise on the south coast of England: advising the

473 decision-makers. Transactions of the Institute of British Geographers, 22(1), 13-30. Retrieved from

474 http://www.jstor.org/stable/623048

475 Census (2010). Profile of General Population and Housing Characteristics: 2010 Demographic Profile Data, U.S.

476 Census Bureau,

477 http://factfinder.census.gov/faces/tableservices/jsf/pages/productview.xhtml?pid=DEC_10_DP_DPDP1\&prodType= 478 table 
Census (2015). Income - Current Population Survey, Table HINC-05 Percent Distribution of Households, by Selected Characteristics Within Income Quintile and Top 5 Percent in 2014, U.S. Census Bureau, http://www.census.gov/hhes/www/cpstables/032015/hhinc/toc.htm

Christensen, J. H., Kumar, K. K., Aldria, E., An, S.-I., Cavalcanti, I. F. a., Castro, M. De, ... Zhou, T. (2013).

Craft, C., Clough, J., Ehman, J., Jove, S., Park, R., Pennings, S., ... Machmuller, M. (2009). Forecasting the effects of accelerated sea-level rise on tidal marsh ecosystem services. Frontiers in Ecology and the Environment, 7(2), 7378. http://doi.org/10.1890/070219

CTDOH (2013). Community Development Block Grant - Disaster Recovery Owner Occupied Rehabilitation and http://www.climatechange.gov.au/publications/coastline/climate-change-risks-to-australias-coasts.aspx

500 FEMA (2013). Connecticut: One Year Later. http://www.fema.gov/disaster/4087/updates/connecticut-one-year-later

506 Goklany, I. M. (2007). Integrated strategies to reduce vulnerability and advance adaptation, mitigation, and sustainable development. Mitigation and Adaptation Strategies for Global Change, 12(5), 755-786. http://doi.org/10.1007/s11027-007-9098-1

509 Gornitz, V., Couch, S., \& Hartig, E. K. (2002). Impacts of sea level rise in the New York City metropolitan area. 510 Global and Planetary Change, 32(1), 61-88. http://doi.org/10.1016/S0921-8181(01)00150-3

511 Hamin, E. M., \& Gurran, N. (2009). Urban form and climate change: Balancing adaptation and mitigation in the 512 U.S. and Australia. Habitat International, 33(3), 238-245. http://doi.org/10.1016/j.habitatint.2008.10.005

513 Hinkel, J., Lincke, D.,Vafeidis, A.T., Perrette, M., Nicholls, R.J., Tol, R.S.J., Marzeion, B., Fettweis, X., Ionescu, 514 C., and Levermann, A. (2014). Coastal flood damage and adaptation costs under $21^{\text {st }}$ century sea-level rise.

515 Proceedings of the National Academy of Sciences, 111(9), 3292-3297. 
Horton R, Yohe G, Easterling W, Kates R, Ruth M, Sussman E, Whelchel A, Wolfe D, Lipschultz F. (2014). Ch. 16 : Northeast. Climate Change Impacts in the United States: The Third National Climate Assessment, J.M. Melillo, T.C. Richmond, G.W. Yohe, Eds., U.S. Global Change Research Program, 16-1-nn.

HUD (2013). HUD Announces first round of allocations of Hurricane Sandy recovery funds. HUD No. 13- 014. February 6, 2013. http://portal.hud.gov/hudportal/HUD?src=/press/press_releases_media_advisories/2013/HUDNo.13-014

Kettle, N. P. (2012). Exposing compounding uncertainties in sea level rise assessments. Journal of Coastal Research, 28(1), 161-173. http://doi.org/10.2112/JCOASTRES-D-12-00

Kirwan, M. L., \& Megonigal, J. P. (2013). Tidal wetland stability in the face of human impacts and sea-level rise. Nature, 504(7478), 53-60. http://doi.org/10.1038/nature12856

Kuhn, M., Tuladhar, D., Corner, R. (2011). Visualising the spatial extent of predicted coastal zone inundation due to sea level rise in south-west Western Australia. Ocean \& Coastal Management, 54, 796-806. doi:10.1016/j.ocecoaman.2011.08.005

Kunte, P.D., Jauhari, N., Mehrotra, U., Kotha, M., Hursthouse, A.S., Gagnon, A.S. (2014). Multi-hazards coastal vulnerability assessment of Goa, India, using geospatial techniques. Ocean \& Coastal Management, 95, 264-281. http://dx.doi.org/10.1016/j.ocecoaman.2014.04.024

Lichter, M., Felsenstein, D. (2012). Assessing the costs of sea-level rise and extreme flooding at the local level: A GIS-based approach. Ocean \& Coastal Management, 59, 47-62. doi:10.1016/j.ocecoaman.2011.12.020

Maantay, J., \& Maroko, A. (2009). Mapping urban risk: Flood hazards, race, \& environmental justice in New York. Applied Geography, 29(1), 111-124. http://doi.org/10.1016/j.apgeog.2008.08.002

Medina, Daniel E., Jacquelyn Monfils, and Zachary Baccata. (2011). "Green Infrastructure Benefits for Floodplain Management: A Case Study." Stormwater, November-December issue. Available at http://www. stormh2o.com/SW/Articles/Green_Infrastructure_Benefits_for_Floodplain_Manag_15593.aspx

Nelson, E. J., Kareiva, P., Ruckelshaus, M., Arkema, K. K., Geller, G., Girvetz, E., ... Tallis, H. (2013). Climate change's impact on key ecosystem services and the human well-being they support in the US. Frontiers in Ecology and the Environment, 11(9), 483-493. http://doi.org/10.1890/140022

NYC (2013). A Stronger, More Resilient New York. PlaNYC, New York City.

Nicholls, R. J., Leatherman, S. P., Dennis, K. C., Volonté, C. R., Nicholls, R. J., \& Volonte, C. R. (1995). Impacts and Responses to Sea-Level Rise : Qualitative and Quantitative Assessments. Journal of Coastal Research, Special Is(14), 26-43.

Nicholls, R. J., \& Vega-Leinert, A. C. de la. (2008). Implications of sea-level rise for Europe's coasts: An introduction. Journal of Coastal Research, 24(2), 285-287. http://doi.org/10.2112/07A-0002.1

Nicholls, R. J., Marinova, N., Lowe, J. a, Brown, S., Vellinga, P., de Gusmão, D., ... Tol, R. S. J. (2011). Sea-level rise and its possible impacts given a "beyond $4^{\circ} \mathrm{C}$ world" in the twenty-first century. Philosophical Transactions. Series A, Mathematical, Physical, and Engineering Sciences, 369(1934), 161-81. http://doi.org/10.1098/rsta.2010.0291 
NOAA 2016. The thirty costliest mainland United States tropical cyclones 1900-2013.

553 http://www.aoml.noaa.gov/hrd/tcfaq/costliesttable.html Accessed May 27, 2016.

554 Özyurt, G., \& Ergin, A. (2010). Improving Coastal Vulnerability Assessments to Sea-Level Rise: A New Indicator-

555 Based Methodology for Decision Makers. Journal of Coastal Research, 262(2), 265-273. http://doi.org/10.2112/08-

$556 \quad 1055.1$

557 Parr, D.T., Wang, G.L., Ahmed, K.F. (2015). Hydrological changes in the U.S. Northeast using the Connecticut

558 River Basin as a case study: Part 2. Projections of the Future. Global and Planetary Change.

559 doi:10.1016/j.gloplacha.2015.08.011

560 Parris, A., Bromirski, P., Burkett, V., Cayan, D., Culver, M., Hall, J., ... Weiss, J. (2012). Global Sea Level Rise 561 Scenarios for the US National Climate Assessment. NOAA Tech Memo OAR CPO, 1-37. Retrieved from 562 http://cpo.noaa.gov/sites/cpo/Reports/2012/NOAA_SLR_r3.pdf

563 Salik, K. M., Jahangir, S., Zahdi, W. U. Z., \& Hasson, S. U. (2015). Climate change vulnerability and adaptation 564 options for the coastal communities of Pakistan. Ocean \& Coastal Management, 112, 61-73.

565 http://doi.org/10.1016/j.ocecoaman.2015.05.006

566 Schleupner, C. (2007). Spatial Assessment of sea level rise on Martinique's Coastal Zone and Analysis of Planning 567 Frameworks for Adaptation. Journal of Coastal Conservation, 11(2), 91-103. http://doi.org/10.1007/sl

568 Seenath, A., Wilson, M., Miller, K. (2016). Hydrodynamic versus GIS modeling for coastal flood vulnerability 569 assessment: Which is better for guiding coastal management?. Ocean \& Coastal Management, 120, 99-109. 570 http://dx.doi.org/10.1016/j.ocecoaman.2015.11.019

571 Smith, K. M. (2006). Integrating Habitat and Shoreline Dynamics Into Living Shoreline Applications. In 572 Management, policy, science and engineering of nonstructural erosion control in the Chesapeake Bay (pp. 9-11).

573 SCRCOG (2008). Census Geographic Places. (Data file). North Haven, CT: South Central Regional Council of 574 Governments.

575 SCRCOG (2016). Updated Parcels. (Data file). North Haven, CT: South Central Regional Council of Governments.

576 Swann, L. (2008). The Use of Living Shorelines to Mitigate the Effects of Storm Events on Dauphin Island, 577 Alabama, USA. Amedrican Fisheries Society Symposium, 64, $11 \mathrm{pp}$.

578 Sweet W, Park J, Marra J, Zervas C, Gill S. 2014. Sea Level Rise and Nuisance Flood Frequency Changes around 579 the United States. NOAA Technical Report NOS CO-OPS 073, 66 pp.

580 Taramelli, a., Valentini, E., \& Sterlacchini, S. (2015). A GIS-based approach for hurricane hazard and vulnerability 581 assessment in the Cayman Islands. Ocean \& Coastal Management, 108, 116-130.

582 http://doi.org/10.1016/j.ocecoaman.2014.07.021

583 U.S. Department of Agriculture. (2000). National Elevation Data. (Data file). Fort Worth, TX: U.S. Geological 584 Survey.

585 UConn MAGIC. (2010). U.S. Census Blocks - Connecticut. (Data file). Washington, D.C.: U.S. Census Bureau. $586 \leq$ http://magic.lib.uconn.edu/magic_2/vector/37800/blockct_37800_0000_2010_s100_census_1_shp.zip >

587 Williams, S. J. (2013). Sea-level rise implications for coastal regions. Journal of Coastal Research, 63, $184-196$. 
Wu, S., Yarnal, B., \& Fisher, a. (2002). Vulnerability of coastal communities to sea-level rise: a case study of Cape May County, New Jersey, USA. Climate Research, 22(3), 255-270. http://doi.org/10.3354/cr022255 